\title{
First Molecular Characterization of Hypoderma actaeon in Cattle and Red Deer (Cervus elaphus) in Portugal
}

\author{
Haroon Ahmed ${ }^{1,2}$, Sérgio Ramalho Sousa ${ }^{3,4}$, Sami Simsek ${ }^{2, *}$, Sofia Anastácio ${ }^{3,5}$, Seyma Gunyakti Kilinc ${ }^{2}$ \\ 'Department of Biosciences, COMSATS Institute of Information Technology (CIIT), Park Road, Chakh Shazad, Islamabad, Pakistan; '2Department of \\ Parasitology, Faculty of Veterinary Medicine, University of Firat, 23119, Elazig, Turkey; ${ }^{3}$ Vasco da Gama University School (EUVG), Av. José R. Sousa \\ Fernandes 197 Lordemão, 3020-210 Coimbra, Portugal; ${ }^{4}$ Interdisciplinary Research Centre on Animal Health, Faculty of Veterinary Medicine, \\ University of Lisbon, (CIISA, FMV, UTL), Pólo Universitário do Alto da Ajuda, Portugal; ${ }^{5}$ Faculty of Pharmacy and Center of Neurosciences and Cell \\ Biology, University of Coimbra, Coimbra, Portugal
}

\begin{abstract}
Hypoderma spp. larvae cause subcutaneous myiasis in several animal species. The objective of the present investigation was to identify and characterize morphologically and molecularly the larvae of Hypoderma spp. collected from cattle (Bos taurus taurus) and red deer (Cervus elaphus) in the district of Castelo Branco, Portugal. For this purpose, a total of 8 larvae were collected from cattle $(n=2)$ and red deer $(n=6)$. After morphological identification of Hypoderma spp. larvae, molecular characterization was based on PCR-RFLP and mitochondrial CO1 gene sequence analysis. All larvae were morphologically characterized as the third instar larvae (L3) of $H$. actaeon. Two restriction enzymes were used for molecular identification of the larvae. Taql restriction enzyme was not able to cut $H$. actaeon. However, Mboll restriction enzyme differentiated Hypoderma species showing 210 and 450 bp bands in $H$. actaeon. Furthermore, according to the alignment of the mt-CO1 gene sequences of Hypoderma species and to PCR-RFLP findings, all the identified Hypoderma larvae were confirmed as $\mathrm{H}$. actaeon. This is the first report of identification of Hypoderma spp. (Diptera; Oestridae) from cattle and red deer in Portugal, based on morphological and molecular analyses.
\end{abstract}

Key words: Hypoderma actaeon, cattle, red deer, phylogenetic analysis, PCR-RFLP, Portugal

\section{INTRODUCTION}

Hypodermosis, one of the most common parasitic diseases in the northern hemisphere [1], is a myiasis caused by warble flies of the genus Hypoderma which is common in Bovidae and Cervidae of the Holarctic region. In Europe, red deer (Cervus elaphus) may be infected by Hypoderma diana and Hypoderma actaeon. H. diana is also found in roe deer (Capreolus capreolus) which is its main host, but $H$. actaeon seems to be restricted to Cervus elaphus [2].

Some epidemiological studies on hypodermosis have been conducted in wild ungulates in central Europe [3,4], France [5], and southern and central Spain [6,7]. In central Spain, an epidemiological study conducted in red deer was based on the inspection of shot animals, during the period of warble detec-

- Received 23 February 2017, revised 6 November 2017, accepted 25 November 2017. *Corresponding author (ssimsek@firat.edu.tr)

(c) 2017. Korean Society for Parasitology and Tropical Medicine

This is an Open Access article distributed under the terms of the Creative Commons Attribution Non-Commercial License (http://creativecommons.org/licenses/by-nc/4.0) which permits unrestricted non-commercial use, distribution, and reproduction in any medium, provided the original work is properly cited. tion. All the third instar (L3) were classified as H. actaeon, and the global prevalence was $61 \%$. The prevalence in yearling and adult deer shot during the official hunting season was $89 \%$ [8]. Despite the life cycle of Hypoderma sp. in deer at the western Mediterranean area is not well known, cattle hypodermosis is recognized all over the world [9].

The third instar Hypoderma larvae (L3) can be identified on the basis of their morphological characters. These characters are peritreme structure and the spinulation pattern (presence/ absence) in their 10th larval segment [2]. More recently, all 4 Hypodermatinae (H. lineatum, H. bovis, H. diana, and H. actaeon) were accurately characterized by scanning electron microscopy (SEM) by comparing thoracic spines [10]. Additionally, molecular studies on cytochrome $c$ oxidase subunit 1 (CO1) sequences of the mtDNA has been used as a target gene for the identification studies, allowing the distinction of 5 common Hypoderma species together with electron microscopic analysis of key morphological features [11]. Furthermore, Hypoderma spp. have been identified in east Turkey by sequence analysis of mt-CO1 gene and by using PCR-RFLP assay [12].

The identification of Hypoderma larvae described in the liter- 
ature is scarce, and it is mainly based on the morphology of the 3rd instars [2]. On the other hand, PCR-RFLP and nucleotide sequences of regions of mt-CO1 gene have provided precious information on the classification of Hypoderma spp. [13]. Nowadays, the mt-CO1 gene has been extensively used as a target gene in many identification and molecular phylogenetic studies [14], including Hypoderma spp. [12,15]. This study aimed to identify morphologically and molecularly Hypoderma spp. collected from domestic and wild ruminants in Portugal (cattle and red deer), by morphological characterization, PCRRFLP analysis, and sequencing analysis of a specific fragment of mt-CO1 gene.

\section{MATERIALS AND METHODS}

\section{Study area}

The specimens were collected from hunted red deer (6 larvae) and slaughtered cattle (2 larvae) in the region of Castelo Branco $\left(39^{\circ} 8^{\prime} \mathrm{N} ; 7^{\circ} 5^{\prime} \mathrm{W}\right)$ and Idanha-a-Nova $\left(39^{\circ} 9^{\prime} \mathrm{N} ; 7^{\circ} 2^{\prime} \mathrm{W}\right)$ during 2011. Idanha-a-Nova and Castelo Branco are 2 municipalities located at the center of Portugal. Every year in this region, hunting activities are organized to control the population of cervids and wild boars. The samples were collected from shot red deer and slaughtered cattle in an effort of adding some more information about this parasite in domestic and wild ruminants. The 2 municipalities are located at $400 \mathrm{~m}$ of altitude in a region with a Mediterranean climate with continental influence. The annual average temperature is $15.3^{\circ} \mathrm{C}$, and the annual average precipitation $881 \mathrm{~mm}$. July is usual the driest month, and January is the rainiest month.

\section{Sample collection}

Hypoderma spp. naturally infected in red deer (Cervus elaphus) and cattle (Bos taurus taurus) were found by the palpation of larvae on the back, flanks, and chest, and by the examination of skin, subcutaneous soft tissues, and subcutaneous muscles, to check for gross changes, such as congestion, bleeding, nodules or lumpy lesions, cysts, and abscesses or suppurative lesions. Larvae were collected, washed several times in PBS ( $\mathrm{pH} 7.4$ ) to remove mucosal debris, preserved in $70 \%$ ethanol, and stored at $-20^{\circ} \mathrm{C}$ until analysis.

\section{Morphological identification}

The morphological characterization of Hypoderma larvae was performed by using the identification key of Zumpt [2].
Morphological characteristics, such as the shape, size, colour, and pattern of spinulation under a stereomicroscope (Olympus SZX16, Olympus Life Science, Tokyo, Japan) were evaluated. The larval bodies were kept at $70 \%$ ethanol until molecular procedures.

\section{Genomic DNA extraction}

The total gDNA was obtained from the internal tissue of all individual Hypoderma larvae using commercial Genomic DNA Purification kit ${ }^{\circledR}$ (K0512, Fermentas, Vilnius, Lithuania) with slight modifications. For instance, prior to isolation of gDNA, the ethanol-fixed Hypoderma larvae were washed at least 5 times with saline solution (PBS). The digestion of internal tissues was carried out by the incubation overnight at $56^{\circ} \mathrm{C}$ with $200 \mu$ lysis buffer provided by the kit to which $20 \mu$ l proteinase-K $(20 \mathrm{mg} / \mathrm{ml}$ ) (Sigma, St. Louis, Missouri, USA) was added. After the digestion step, the protocol of the manufacturer was followed. The pellet was resuspended in $100 \mu$ elution buffer, and gDNA were stored at $-20^{\circ} \mathrm{C}$ until further use.

\section{PCR}

The amplification of fragments of mt-CO1 gene was done by PCR using conserved specific primers previously described by Otranto et al. [11] (UEA7, 5' -ACAGTTGGAATAGACGTT GATAC-3' and UEA10, 5' ${ }^{\prime}$ TCCAATGCACTAATCTGCCATATTA-3') in a total volume of $50 \mu \mathrm{l}$ containing $5 \mu \mathrm{l} 10 \times$ PCR buffer, $5 \mu \mathrm{l} 25 \mathrm{mM} \mathrm{MgCl}_{2}$, $4 \mu \mathrm{l}$ of each dNTPs, 20 pmol of each primer, $200 \mathrm{ng}$ of template DNA and $1.25 \mathrm{U}$ of Taq DNA polymerase (MBI, Fermentas). The PCR conditions were $2 \mathrm{~min}$ at $95^{\circ} \mathrm{C}$ (initial denaturation), 40 cycles of $1 \mathrm{~min}$ at $95^{\circ} \mathrm{C}, 1 \mathrm{~min}$ at $52^{\circ} \mathrm{C}$ and $1 \mathrm{~min}$ at $72^{\circ} \mathrm{C}$ and finally $7 \mathrm{~min}$ at $72^{\circ} \mathrm{C}$ (final extension). The PCR products were separated on agarose gel (1.4\%) and stained with ethidium bromide.

\section{PCR-RFLP}

The PCR products were digested at $65^{\circ} \mathrm{C}$ overnight with restriction endonuclease TaqI, using buffers recommended by the manufacturer (MBI, Fermentas) in $36 \mu \mathrm{l}$ of the final volume reaction mix, containing $20 \mu \mathrm{l}$ of PCR product, $10 \mathrm{U}$ enzyme (TaqI, $10 \mathrm{U} / \mu \mathrm{l}), 4 \mu \mathrm{l}$ restriction buffer, and $11 \mu \mathrm{l}$ distilled water. The restriction fragments were separated on 3\% agarose gels and stained with ethidium bromide [11].

For MboII enzyme, PCR products were digested at $37^{\circ} \mathrm{C}$ during $5 \mathrm{hr}$, using buffers as recommended by the manufacturer (MBI, Fermentas) in a final $31 \mu \mathrm{l}$ volume reaction mix, con- 
taining $10 \mu \mathrm{l}$ of PCR product, $10 \mathrm{U}$ enzyme (MboII $10 \mathrm{U} / \mu \mathrm{l}$ ), 2 $\mu \mathrm{l}$ restriction buffer, and $18 \mu \mathrm{l}$ distilled water. The restriction fragments were separated on 3\% agarose gels and stained with ethidium bromide. All gDNA positive control samples (previously sequenced) were provided by the Molecular Parasitology Laboratory of Veterinary Faculty, Firat University, Turkey.

\section{mt-CO1 sequence and phylogenetic analysis}

All the mt-CO1 PCR products of cattle and deer samples were sequenced. Their nucleotide sequence analysis was undertaken by BLAST algorithms and databases from the National Center for Biotechnology (http://www.ncbi.nlm.nih.gov).

Multiple sequence alignment and phylogenetic tree construction of the obtained sequence of the $\mathrm{mt}-\mathrm{CO} 1$ gene were performed with the use of CLC Main Workbench software (CLC, Aarhus, Denmark) [16]. Unidirectional DNA sequence analysis of the mt-CO1 gene of all samples were performed. Unreliable ends of the raw sequences were trimmed, and then the phylogenetic tree was built using the neighbour-joining method [17]. Based on pairwise comparisons, sequence differences were calculated using the CLC Main Workbench software. The reliability of the inferred tree was evaluated by bootstrap analysis of 1,000 replicates. Reference sequences of $H$. bovis (KT600293), H. lineatum (KP965726), H. diana (AF 497763), H. sinense (KT600316), H. tarandi (AF497764), and H. actaeon (AF497765) were also included for phylogenetic analysis.

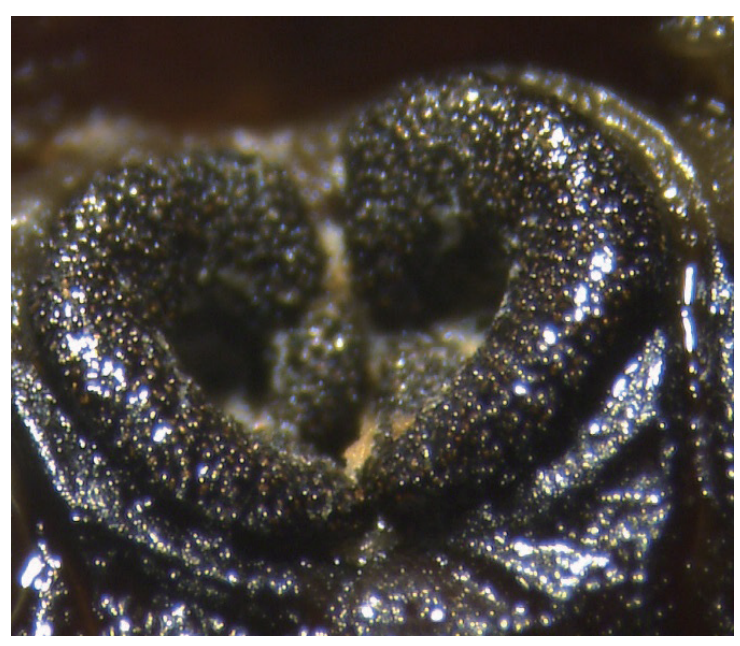

Fig. 1. Morphological identification of Hypoderma actaeon larvae. Plate cover by the ecdysal scar. The evident "C" shaped structures is raised and the rima is quite open.

\section{RESULTS}

\section{Morphology}

According to the morphological characterization of Hypoderma spp. based on the 3rd instar larvae by stereomicroscope, all of the larvae $(\mathrm{n}=8)$ from cattle and red deer were classified as $H$. actaeon. The spiracular plate of $H$. actaeon was recessed, and the ecdysal scar well below the surface of the spiracular plate. The evident " $C$ " shaped structures was raised, and the rima was quite open (Fig. 1).

\section{PCR-RFLP}

Furthermore, all the specimens were classified as H. actaeon by molecular identification of Hypoderma spp. larvae which was carried out by PCR-RFLP and mt-CO1 gene sequence analysis. Concerning to PCR-RFLP analysis, TaqI restriction enzyme was used to discriminate the Hypoderma species. However, it was impossible to cut fragments of mt-CO1 gene by PCR-RFLP while MboII restriction enzyme was able to discriminate Hypoderma species by the presence of $688 \mathrm{bp}$ bands observed in H. bovis and $H$. lineatum (no cut), used as a control, and by the presence of 210 and $450 \mathrm{bp}$ bands of H. actaeon (Fig. 2).

\section{mt-CO1 sequence analysis}

Blast analysis of Hypoderma spp. sequences in the NCBI was performed and confirmed all the specimens as $\mathrm{H}$. actaeon. We found that these sequences matched with mostly mt-CO1.

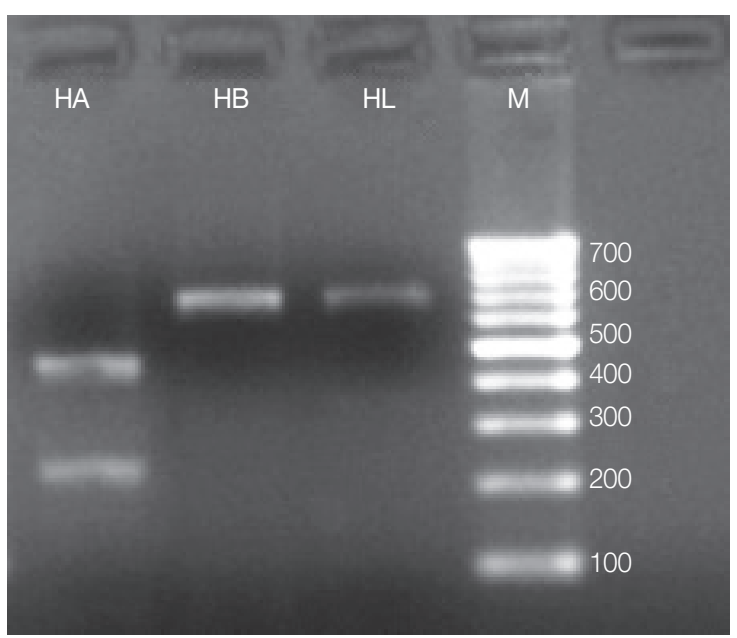

Fig. 2. Molecular differentiation of Hypoderma spp. isolates (red deer/cattle) by PCR-RFLP based on Mboll restriction enzyme. M, Marker-100 bp; HB, Hypoderma bovis (688 bp bands); HL, Hypoderma lineatum (688 bp); HA, Hypoderma actaeon (210 and 450 bp). 


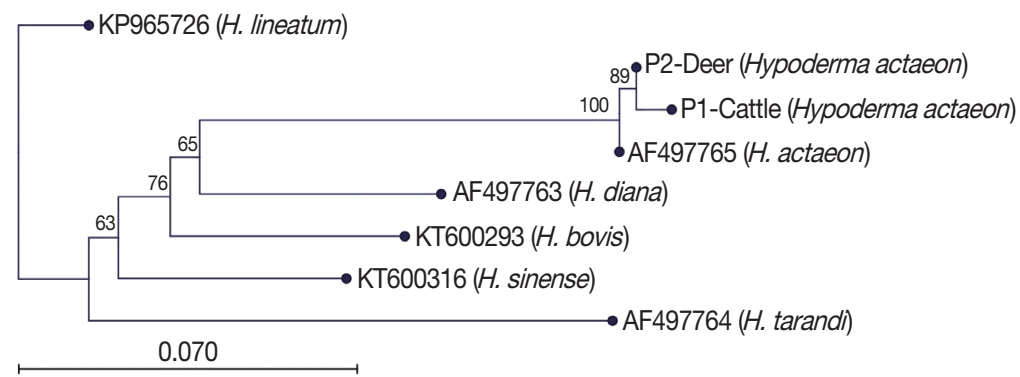

Fig. 3. Phylogenetic tree view of the aligned sequences.

Then, the sequence results were performed to pairwise analysis for genetic distances. The pairwise comparison and phylogenetic tree obtained from the sequences confirmed that all $\mathrm{Hy}$ poderma larvae were classified as H. actaeon (Fig. 3). All sequence results were similar and there were no important variation among the sequences.

\section{DISCUSSION}

Hypodermosis shows a worldwide distribution [9] and has been reported in 55 tropical and subtropical countries [18]. This parasitosis is also prevalent in European countries. So far there are limited reports in Portugal despite the high prevalence reported in a neighbour country (i.e. Spain) [19]. Deer hypodermosis is very common in Spain. The prevalence was estimated at $80 \%$ [6] and a high intensity of parasite infection was reported (average of 40 larvae) [6,7]. Notwithstanding, more recent studies showed a slight decrease of the prevalence, ranging from $44.8 \%$ [20] to $61.0 \%$ [8], but the infection intensity remains similar (average of 38.3 larvae) [20].

In wild ungulates, high prevalences of hypodermosis have been reported. In Hungary, 65\% of red deer (Cervus elaphus) and $98 \%$ of roe deer (Capreolus capreolus) were infected by $H$. diana while $93 \%$ of red deer were infected with $H$. actaeon [4]. H. tarandi was found in $97 \%$ to $100 \%$ of Canadian caribou (Rangifer tarandus) [21]. In Europe, H. actaeon is recognized as a typical parasite in red deer [2]; however, an incidence of $89 \%$ of hypodermosis in red deer caused by $H$. diana was reported in Spain [6]. These species are known as strictly host-specific [2]. A seroprevalence study of bovine hypodermosis was conducted in the area of upper Tagus river of Portugal showing a seroprevalence of $35 \%$ [22].

This study describes for the first time the presence of $\mathrm{H.ac}$ taeon in red deer and cattle in Portugal. Regarding the red deer, these findings are in agreement with other studies conducted in Spain where H. actaeon was found in red deer and in roe deer (Capreolus capreolus) from central Spain [7,23]. It was not possible to confirm the presence of $H$. diana as found in southern Spain [6]. Notwithstanding, the low number of specimens does not allow the exclusion of the possibility of coexistence of these 2 species as it was also observed in Hungary [4].

A limited number of studies based on the morphological identification of Hypoderma larvae from cattle and especially red deer (Cervus elaphus) are available in the literature. These were mainly based on the morphological features of the 3rd instars [2]. In the present study, all the Hypoderma larvae were morphologically identified as $\mathrm{H}$. actaeon. Regarding the deer hypodermosis, $H$. diana and $H$. actaeon are the main species that infect deer. These 2 species are morphologically different, since $H$. diana has a distinctive band of spines on the cephalic segment, which are absent in $\mathrm{H}$. actaeon. These differences facilitate the identification of these species [10].

Nevertheless, morphological discrimination of Hypoderma spp. is not considered an absolutely reliable methodology for identification. Hypoderma from different geographical origins may present only slight morphological differences. Similarly, it is very difficult to differentiate $H$. lineatum, $H$. bovis, and $H$. actaeon from cattle and red deer due to the colour and spinulation patterns. Other difficulties in morphological identification might be due to inappropriate preservation and dark brown colour of the larvae. A more reliable method to identify Hypoderma larvae is using PCR-RFLP based on mt-CO1 gene and sequence analysis [24]. The molecular identification based on mt-CO1 gene has been used to differentiate the 5 common $\mathrm{Hy}$ poderma spp. (i.e., H. diana, H. bovis, H. lineatum, H. actaeon, and $H$. tarandi) [11].

In the present study, a comparative differentiation of $H$. bovis and $H$. acteon was done by using PCR-RFLP based on TaqI and MboII restriction enzymes. It reflects the significance of PCR-RFLP method for the accurate identification of Hypoderma 
spp. in cattle and red deer. The molecular characterization of Hypoderma spp. (H. bovis, H. lineatum, and H. sinense) was based on mt-CO1 gene [25]. According to the mt-CO1 gene sequences analysis and PCR-RFLP findings, all the larvae were molecularly characterized as $H$. actaeon confirming the results of the morphological identification. Our findings on molecular characterization are similar to those reported by Otranto et al. [11,26]. In Portugal, no previous studies based on morphological and molecular characterization of Hypoderma spp. are available.

A partial mt-CO1 gene was successfully used for amplification of the Hypoderma spp. The gene segment was sequenced and compared to previously determined sequences of $H$. bovis and $H$. lineatum. The evolutionary rate of different insects (order; Orthoptera) has been determined by using mt-CO1 gene [27]. The evolutionary rate of different insects (Orthoptera, Diptera, and Hymenoptera) has been determined by using $\mathrm{mt}-\mathrm{CO} 1$ gene $[14,27]$. To define the relationships of $H$. sinense to $H$. lineatum and $H$. bovis, the mt-CO1 gene was used as a target for sequence analysis. The clear differentiation of Hypoderma species ( $H$. sinense from $H$. lineatum and $H$. bovis) was done by comparing the mt-CO1 gene sequences.

In conclusion, our findings allowed us to state confidently that $H$. actaeon is an occurring species in red deer and cattle in Portugal. PCR-RFLP is recommended for species identification as compared to sequencing. This study opens new directions of research on Hypoderma spp. in different hosts and different geographical areas of Portugal.

\section{ACKNOWLEDGMENT}

We are very thankful to TUBITAK (2216-research fellowship program for international researchers) for providing an opportunity and funding to the work developed by Dr. Haroon Ahmed.

\section{CONFLICT OF INTEREST}

The authors fully declare no financial or other potential conflict of interest.

\section{REFERENCES}

1. Boulard C. Durably controlling bovine hypodermosis. Vet Res 2002; 33: 455-464.

2. Zumpt F. Myiasis in Man and Animals in the Old World. London, UK. Butterworths. 1965, pp 205-214.

3. Brauer FM. Monographie der Oestriden. Wien, Austria. Druck
Von Carl Unberreuter. 1863, pp 291.

4. Sugar L. On the incidence of larvae of Hypodermatidae in the games and wild rodents of Hungary. Parasit Hung 1976; 9: 8596.

5. Maes S, Boulard C. Deer Myiasis in France. COST Action 2000; 833: 181-186.

6. Martínez-Gómez F, Hernández-Rodriguez S, Ruiz-Sanchez P, Molina-Rodero R, Martínez-Moreno A. Hypodermosis in the red deer Cerrus elaphus in Cordoba, Spain. Med Vet Entomol 1990; 4: 311-314.

7. Pérez JM, Granados JE, Ruiz-Martínez I. Studies on the hypodermosis affecting red deer in central and southern Spain. J Wildlife Dis 1995; 31: 486-490.

8. San Miguel JM, Álvarez G, Luzón M. Hypodermosis of red deer in Spain. J Wildlife Dis 2001; 37: 342-346.

9. Ahmed H, Afzal MS, Mobeen M, Simsek S. An overview on different aspects of hypodermosis: current status and future prospects. Acta Trop 2016; 162: 35-45.

10. Colwell DD, Martínez-Moreno FJ, Martínez-Moreno A, Hernández-Rodríguez S, de la Fuente-López C, Alunda JM, Hall MJ. Comparative scanning electron microscopy of third-instar Hypoderma spp. (Diptera: Oestridae). Med Vet Entomol 1998; 12: 181-186.

11. Otranto D, Traversa D, Tarsitano E, Stevens J. Molecular differentiation of Hypoderma bovis and Hypoderma lineatum (Diptera, Oestridae) by polymerase chain reaction-restriction fragment length polymorphism (PCR-RFLP). Vet Parasitol 2003; 112: 197201.

12. Balkaya I, Simsek S, Saki CE. A serological and molecular survey of cattle hypodermosis in east-Turkey. Vet Parasitol 2010; 173: 287-291.

13. Otranto D, Colwell DD, Traversa D, Stevens JR. Species identification of Hypoderma affecting domestic and wild ruminants by morphological and molecular characterization. Med Vet Entomol 2003; 17: 316-325.

14. Lunt DH, Zhang DX, Szymura JM, Hewitt GM. The insect cytochrome oxidase I gene: evolutionary patterns and conserved primers for phylogenetic studies. Insect Mol Biol 1996; 5: 153165.

15. Li W, Ano H, Jin J, Nasu T, Ma Y, Zhu X, Makimura S. Cytochrome oxidase I gene sequence of Hypoderma sinense infecting yaks in the Qinghai-Tibet high plateau of China. Vet Parasitol 2004; 124: 131-135.

16. Knudsen B, Knudsen T, Flensborg M, Sandmann H, Heltzen M, Andersen A, Dickenson M, Bardram K, Steffensen PJ, Monsted S. CLC Genomics Workbench. Version 5.5. Aarhus, Denmark, CLC bio. 2007.

17. Saitou N, Nei M. The neighbor-joining method: a new method for reconstructing phylogenetic trees. Mol Biol Evol 1987; 4: 406-425.

18. Hassan MU, Khan MN, Abubakar M, Waheed HM, Iqbal Z, Hussain M. Bovine hypodermosis-a global aspect. Trop Anim Health Prod 2010; 42: 1615-1625. 
19. Panadero R, López C, Díez N, Paz A, Díez P, Morrondo P. Influence of internal and environmental factors on the distribution and occurrence of Hypoderma (Diptera: Oestridae) in cattle in Galicia (Northwest of Spain). J Med Entomol 2000; 37: 27-28.

20. de la Fuente-López C, Santín-Durán M, Alunda JM. Seasonal changes in prevalence and intensity of Hypoderma actaeon in Cervus elaphus from central Spain. Med Vet Entomol 2001; 15: 204207.

21. Thomas DC, Kiliaan HPL. Warble infestations in some Canadian caribou and their significance. Rangifer 1990; 3: 409-417.

22. Reina D, Martínez J, Neto F, Hernández S, Navarrete I. Bovine hypodermosis in Portugal: the first seroepidemiological study of livestock animals from the area of the upper Tajo river. En: COST-833: Mange and Myiasis of Livestock 2000; 113-116.

23. Panadero R, Varas G, Pajares G, López C, Díaz P, Díez-Baños P,
Morrondo P. First report of an infestation by Hypoderma actaeon in roe deer (Capreolus Capreolus). XXIX Congress. Parasites, Poverty and Commitment. 2016; pp 225.

24. Otranto D, Stevens JR. Molecular approaches to the study of myiasis causing larvae. Int J Parasitol 2002; 32: 1345-1360.

25. Ahmed H, Simsek S, Saki CE, Kesik HK, Gunyakti Kilinc SG. Molecular characterization of Hypoderma spp. in domestic ruminants from Turkey and Pakistan. J Parasitol 2017; 103: 303-308.

26. Otranto D, Tarsitano E, Giangaspero A, Puccini V. Differentiation by polymerase chain reaction-restriction fragment length polymorphism of some Oestridae larvae causing myiasis. Vet Parasitol 2000; 90: 305-313.

27. Zhang DX, Szymura, JM, Hewitt GM. Evolution and structural conservation of the control region of insect mitochondrial DNA. J Mol Evol 1995; 40: 382-391. 